TITLE:

\title{
Generation of Pluripotent Stem Cells from Adult Mouse Liver and Stomach Cells(Abstract_要旨)
}

AUTHOR(S):

Aoi, Takashi

\section{CITATION:}

Aoi, Takashi. Generation of Pluripotent Stem Cells from Adult Mouse Liver and Stomach Cells. 京都大学, 2008, 博士(医学)

ISSUE DATE:

2008-05-23

URL:

http://hdl.handle.net/2433/124215

RIGHT: 


\section{京都大学 博士 (医学) \\ 氏 名 青井 貴之 \\ 論文題目 \\ Generation of Pluripotent Stem Cells from Adult Mouse Liver and \\ Stomach Cells (成体マウス肝および胃細胞からの多能性幹細胞樹立)}

(論文内容の要旨)

4つの転写因子 (Oct3/4、Sox2, c-Myc，KIff) をレトロウイルスベクターを用いて導入することにより、、 ウス及びヒトの線維芽細胞は初期化され、胚性幹細胞 (Embryonic Stem cell, ES 細胞) に類似した未分化 な状態となる。人工多能性幹細胞(induced Pluripotent Stem cell, iPS 細胞)とよばれるこれらの細胞は、 種々の病態研究のために患者特異的な幹細胞を作成する方法であることなどから期待されている。しか し、iPS 細胞誘導の分子機構は不明である。iPS 細胞の誘導効率が低いことは、その由来が線維芽細胞 培養中に存在する未分化幹細胞である可能性を示唆するものである。またレトロウイルスがゲノム上の特 定の部位に挿入されることが iPS 細胞の誘導に必須である可能性も考えられた

本論文では、成体マウスの肝細胞及び胃上皮細胞から iPS 細胞を樹立した。

はじめに、ES 細胞および初期胚で特異的に発現するF F X 15 遺伝子座に薬剤而性遺伝子を挿入した マウスを用いた。このマウスから得た細胞は、未分化状態になった時のみ薬剂而性遺伝子を発現しする ため、初期化された細胞を選択することが出来る(Fbx15-iPS 細胞)。このマウスの肝、胃上皮初代培養細 胞からiPSを樹立することが出来た(iPS-Hep, iPS-Stm)。遺伝子発現や、DNA メチル化状態などの点で、 マウス線維芽細胞から得た Fbx15-iPS 細胞は、遺伝子発現や、DNA メチル化状態の点で、 ES 細胞とは 異なっているものであるのに対し、肝および胃上皮から同じ方法で誘導したiPS細胞においては、これら は ES 細胞に匹敵するものであった。

また、分化多能性を調べるために、、ウス胚盤胞に iPS-Hep および-Stm 細胞を移植してキメラマウス 作成した。iPS-Hep/Stm はマウスの発生に寄与し、成体のキメラマウスが得られた。さらに、生殖細胞 系列に寄与して、次世代に引き継がれた。これは、胎児および成体マウス線維芽細胞由来のFbx15-iPS 細胞のキメラは胎生致死となるのと大きく異なる結果であった。これまでに、マウス胎児線維芽細胞か

ら、ES 細胞および初期胚特異的遺伝子 Nanog の発現を指標とした選択をすることにより樹立した Nanog-iPS 細胞では、成体キメラマウスおよびその子孫が得られることが分かっていたが、それらのマウ スでは高率に腫場を発生するといら問題があった。しかし、iPS-Hep や iPS-Stm のキメラおよびその子孫 では、腫瘍は発生しなかった。

次に、線維芽細胞由来の IPS 細胞では、4種の因子を発現するレトロウイルスがそれぞれ1〜12コピ 一挿入されているのに対し、iPS-Hep およびiPS-Stmではそれぞれ1〜4コピーと挿入数は少ないことが 分からた。さらに、4つのクローンでレトロウイルスの挿入部位を調べたところ、染色体上にランダムに分 布し、挿入部位の遺伝子の機能や細胞内局在にも特定の傾向は認められなかった。

最後に、 lineage tracing の手法を用いて、iPS-Hep の由来細胞を調べた。アルブミン遺伝子を一旦発 現した細胞およびそれに由来する細胞では、 $\beta$ ガラタトシダーゼが発現するマウスを作成し、この肝初 代培養細胞から iPS を樹立し、X-gal 染色を行った結果、ほとんどのクローンが陽性となった。このことか ら、iPS-Hep はアルブミン陽性細胞に由来することが分かった。

以上の結果から、4つの因子の導入により、少なくともアルブミンプロモーターが活性化する段階まで 分化した体細胞が初期化することが分かった。さらに、iPS-Hep および iPS-Stm においては特定の部位 へのレトロウイルスの挿入を必要としないものであることが分かった。このことは、ゲノムへの遺伝子の挿 人といら、患者への移植後の腫崵発生の危険をはらむ方法によらずに、 $\mathrm{iPS}$ 細胞を作成し得る可能性を 示唆するものである。
（論文審査の結果の要旨）

iPS細胞はマウスやヒトの体細胞に4つあるいは3つの転写因子を導入することにより樹立され 万多能性幹細胞であり、胚性幹細胞と同様に、ほぼ無限に増殖すると共に、様々な細胞に分化 できる。iPS細胞は同一個体の体細胞から樹立するため、倫理的問題が少なく、移植後の拒絶反応 も回避できることなどから、再生医療への応用が期待されるのみならず、創薬、病態解明研究のツ 一ルとしても有力である。

しかし、iPS細胞が樹立される機序は不明である。iPS細胞の樹立効率が低いことから、線維芽 細胞培養に含まれている特殊な未分化細胞が洋細胞の由来である可能性が考えられてきた。

また、導入因子がレトロウイルスにより染色体上のある特定の位置に挿入されることが必須である という可能性も考えられてきた。

本研究で申請者らは、成体マウスの肝および胃の細胞に、線維芽細胞と同じく4つあるいは 3 つの転写因子を導入することにより、iPS細胞を樹立することに成功した。こうして得られたiPS 細胞は従来のものと比較して、染色体に挿入された導入遺伝子の数が少なく、その挿入部位に特定 の傾向は見られなかった。培養中に含まれる未分化な細胞ではなく、少なくともアルブミンを発現 する段階にまで分化した細胞からiPSが誘導されることも確かめられた。

これらの結果から、今後、遺伝子の組み込みを伴わない、より安全な方法によるiPS 細胞樹立が 可能であることが示唆された。

以上の研究は、人工多能性幹細胞誘導の分子機構の解明に貢献し、幹細胞生物学および再生医療 の発展に寄与するところが多い

したがって、本論文は博士(医学)の学位論文として価値のあるものと認める。

なお、本学位授与申請者は、平成 20 年 3 月 10 日実施の論文内容とそれに関連した試問を受け、合 格と認められたものである。 